Sharif University of Technology
Scientia Iranica
TCIENTIA
I RAN ICA
http://scientiairanica.sharif.edu

\title{
Near-fault ground motion effects on the responses of tall reinforced concrete walls with buckling-restrained brace outriggers
}

\author{
H. Beiraghi* \\ Department of Civil Engineering, Mahdishahr Branch, Islamic Azad University, Mahdishahr, Iran. \\ Received 6 August 2016; received in revised form 6 January 2017; accepted 4 February 2017
}

\section{KEYWORDS}

Reinforced concrete;

Core-wall;

Plastic hinge;

BRB;

Outrigger;

NLTHA;

Near-fault.

\begin{abstract}
In this study, the responses of reinforced concrete core-wall structures connected to the outside columns by Buckling-Restrained Brace (BRB) outriggers in tall buildings were investigated. The buildings were subjected to forward directivity Near-Fault (NF) and ordinary Far-Fault (FF) ground motions. According to the current codes for the DBE level, the response spectrum analysis procedure was applied to analyze and design the structures. The nonlinear fiber element approach was used to simulate the reinforced concrete core-walls. Nonlinear time history analysis was implemented using $14 \mathrm{NF}$ as well as $14 \mathrm{FF}$ records at $\mathrm{MCE}$ level. In the core-wall, the results showed that the mean moment demand envelope and the mean shear demand envelope obtained from the NF records were approximately similar to the corresponding demand envelopes from FF records. The reason had to do with extending plasticity all over the $\mathrm{RC}$ core-wall, which was subjected to both sets of records. The overall responses of the reinforced concrete core-wall with BRB outrigger system were in acceptable range both for NF and FF earthquakes. In this study, the largest curvature ductility demand in the reinforced concrete core-wall took place at levels just above the outriggers.
\end{abstract}

(C) 2018 Sharif University of Technology. All rights reserved.

\section{Introduction}

Tall building structures subjected to earthquake loads usually undergo significant displacements due to large shear forces and heights. Hence, it is very important to use an effective seismic resistance structural system. In up to 40-story buildings, all seismic lateral loads are resisted only by a core-wall system. The efficiency of these systems against lateral displacements significantly decreases in tall buildings [1]. In the outrigger systems, exterior columns are connected to the interior core-wall. Consequently, the exterior columns resist the

\section{*. E-mail address: h.beiraghi@msh-iau.ac.ir}

doi: $10.24200 /$ sci.2017.4205 rotation of central core-wall and reduce the lateral displacements of the building as well as bending moment at the core-wall base [2-6].

Outrigger system causes lateral stiffness increases of up to 25 to $30 \%$ as compared to a system without such trusses [7]. Rutenberg and Tal [8] investigated the drift reduction in uniform and non-uniform belted structures with rigid outriggers under different lateral load distributions. In order to reduce displacement of the roof subjected to the wind load, the optimum location for a single outrigger was studied [7] and an approximate analytical method was proposed. In a core-wall structure system with one rigid outrigger subjected to the uniformly distributed lateral load, the optimum location was obtained approximately at $0.5 \mathrm{H}$, where $\mathrm{H}$ is the total height of the structure. 
The optimum location of the outriggers subjected to triangular lateral load was slightly higher than that calculated for uniformly distributed load $[2,9]$.

Many studies have been conducted on structures with damped outriggers. Zhou and $\mathrm{Li}$ [10] investigated the numerical dynamic response of outrigger systems under various earthquake loads. They concluded that increasing the earthquake intensity would make the influence of viscous damper more obvious. A numerical study was carried out on a single outrigger with smart damping devices in a tall building [11].

Bobby et al. [12] developed a performance-based topology optimization analysis for wind sensitive tall buildings. Lee and Tovar [13] proposed a structural design method for outrigger location in tall buildings using structural topology optimization. Chen et al. [14] investigated a simplified model with two viscous dampers attached to the end of outriggers, and the optimum location and damping coefficient of damper were calculated.

Commonly, Buckling-Restrained Brace (BRB) frame is a diagonally braced frame. This kind of frame is a concentrically braced one. The relevant codes of some countries do not provide provisions for design of such systems [15] and some codes, such as AISC2010 [16] and Seismic Provision for Structural Steel Buildings, have prescribed a response modification factor for such systems. For Buckling Restrained Brace (BRB) frames, some researchers believe that the response modification factor decreases as the height of the structure increases $[17,18]$.

Reinforced Concrete (RC) core-wall is a usual structural system used in tall buildings [19]. In cantilever RC walls, the plastic hinge forming should preferably be located at the base region of the wall [2022]. Tall RC cantilevered walls are strongly affected by higher mode effects [23]. This can change the responses of core-wall structures [24]. Also, in steel moment frame, due to higher mode effects, only the elements located in the upper stories yield and the contribution of plastic rotation of the lower stories of the structure severely decreases [25].

Forward directivity Near-Fault (NF) seismic ground motions have different effects on the performance of the structures when compared with the ordinary Far-Fault (FF) seismic ground motions. There is so much interest in the effects of the NF motions on the structural seismic study. These ground motions, called pulse-like ground motions, have been identified as the cause of severe demands in structures, which can exceed the expected demands typically resulting from Response Spectrum Analysis (RSA) procedure [2630]. Many studies have demonstrated that buildings located in an NF zone undergo highly inelastic responses caused by velocity pulses in the fault normal component of some seismic ground motions [31-33].
No previous study has compared the behavior of tall RC core-wall buildings with BRB outrigger systems subjected to the forward directivity NF and ordinary FF records. In this study, the responses of these kinds of tall structure systems are investigated. The systems are designed based on the current prescriptive seismic codes. The fiber element method is used to prepare the RC core-wall models. Nonlinear time history analysis (NLTHA) of numerical models is performed using two sets of records. Then, the responses are compared; the results show the overall responses of such systems are in acceptable range.

\section{Description and design of buildings}

The 40-, 50-, and 60-story structural models were considered. The core-wall was made of reinforced concrete. The BRB braces were used in the outriggers. The steel peripheral columns and steel beams were also applied for modeling. The beam-column connections and connection of BRBs to other elements were pin type and the connection of the core-wall to the base was fixed type. The level of the outrigger was assumed to be about $0.74 \mathrm{H}$ after a preliminary investigation and referring to other researches [34]. ETABS software was used to create the finite element models, and analyze and design the structures [35]. All vertical loads were carried by the columns as well as RC corewalls. Structural analysis of the models was carried out using lateral loads calculated by the RSA procedure at DBE level. The responses were reduced using the response modification factor. The acceleration response spectrum used in design process is presented in Figure 1. All the analyses and designs of the buildings were carried out only in the $Y$ direction (Figure 2). The general plan of the building and view of the numerical models are presented in Figures 2 and 3. The RC core-wall, outrigger, and connected outside columns were involved in carrying all seismic lateral loads applied to the building. There was no complete space frame providing supports for vertical loads; therefore, a response modification factor equal to 5 was used as prescribed by the NEHRP Seismic

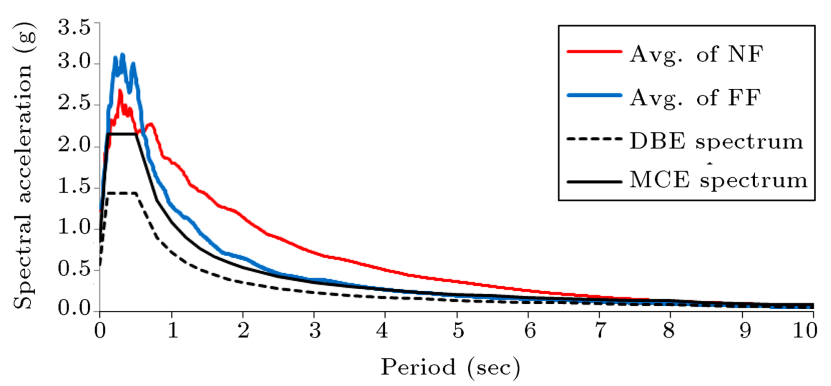

Figure 1. MCE, DBE, mean NF, and mean FF acceleration response spectra. 


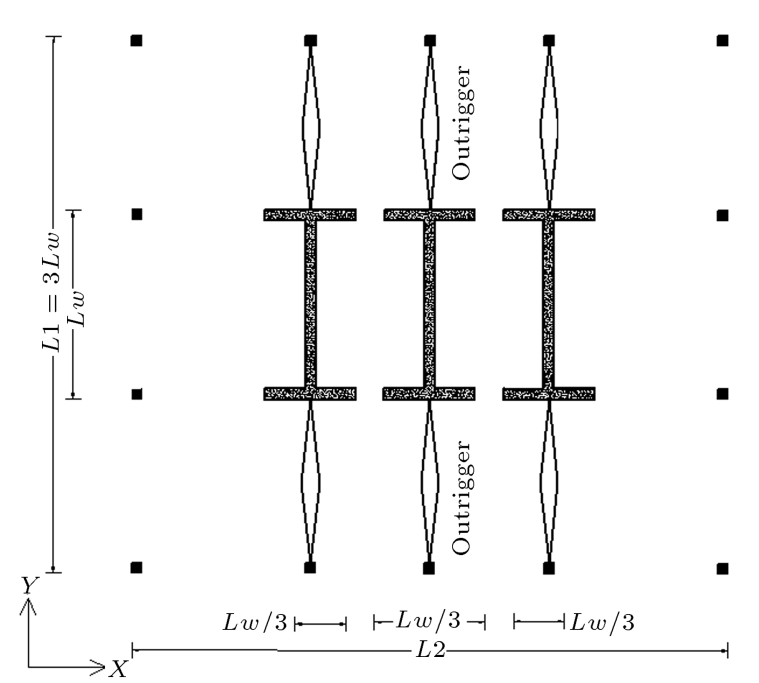

Figure 2. Typical building plan of the examined systems.

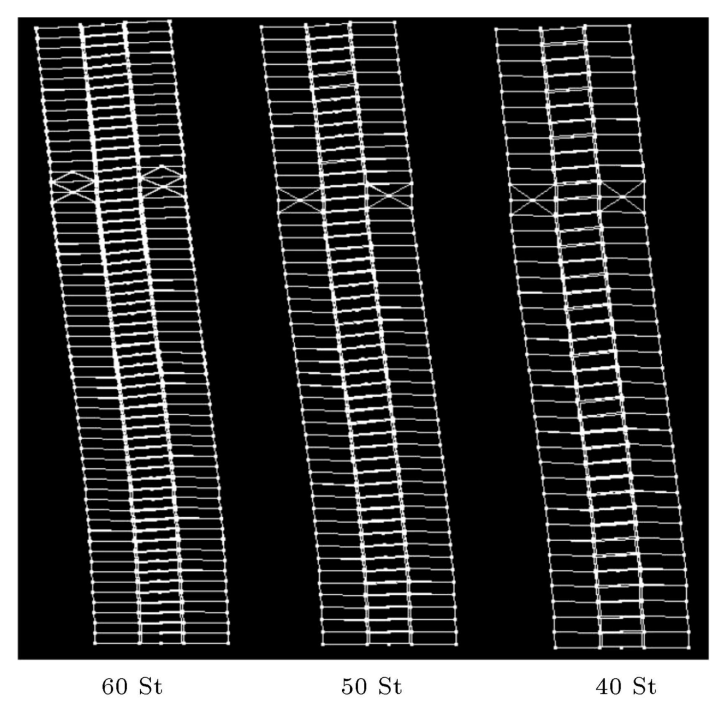

Figure 3. Elevation of the lateral load resisting system (first mode deformation).

Design Technical Brief No. 6 [36]. The mass of each story was assigned to the center of mass of the floors in the models. Design of the components was carried out based on the ASCE 7-2010 [37], ACI 318-2011 [38], and AISC 2010 [16] Codes.

In order to create the $\mathrm{RC}$ wall model in ETABS software, shell elements were used. The effective flexural stiffness of the RC core-wall was considered by using a factor of 0.5 . This value was multiplied by the moment of inertia for the core-wall crosssection. The factor value was in accordance with the stiffness reduction factors recommended in the ACI 318-11 (Sections 8.8 and 10.10). The nominal yielding strength of the steel material of the reinforcing bars and the nominal compression strength of the concrete were 400 and $45 \mathrm{MPa}$, respectively. The steel yielding strength of the column and beam was
$370 \mathrm{MPa}$. In the $Y$ direction, more than $96 \%$ of the modal participating mass ratio resulted from the first 4 translational vibration modes. For the RC corewall, the minimum longitudinal reinforcement ratio was $0.25 \%$ (ACI 318-11 [38]). The calculated boundary element height was in accordance with the ACI-318. The obtained value was extended to 10,7 , and $3 \%$ of the wall height from the base for 40-, 50- and 60-story buildings, respectively.

In order to design the BRB braces, both tension and compression capacities of the braces were considered as $\varphi A_{s} F_{y}$, with $\varphi=0.9$ and $F_{y}=250 \mathrm{MPa}$, where $A_{s}$ is the cross section of the brace element (Sahoo et al. [39]). According to the AISC's Seismic Provisions for Structural Steel Buildings [16], (a) columns in buckling-restrained braced frames need to be checked for the axial load and moment interaction from code level forces and (b) in addition to the tributary gravity loads, the axial load takes place due to the resultant vertical component of all buckling-restrained braces applied to the column. In the simulated columns, the second criterion governs the design and produces larger demand/capacity ratios. For this purpose, the maximum expected compression forces from the brace were calculated as $R_{y} \omega \beta A_{s} F_{y}$, where $R_{y}=1.1$ is for the material overstrength, $\omega=1.25$ considers the strain-hardening effect, and $\beta=1.1$ is the compression overstrength factor [40]. The horizontal component of the brace compression together with unbalanced upward component of the buckling-restrained brace was used to design the beams connected to the BRBs. The specifications of the structures designed using the code prescriptive approach are shown in Table 1 . The calculated longitudinal reinforcement in the RC corewall and the cross-section area of columns are presented in Tables 2 and 3, respectively.

\section{Nonlinear modeling}

The nonlinear dynamic behavior of the structures was evaluated in Perform-3D software [41]. The columns and beams were modeled with elastic members. The nonlinear fiber elements were used to develop the $\mathrm{RC}$ wall models and the BRB elements were applied for brace modeling in the outrigger. After applying the earthquakes, the elastic behavior of beam and column elements was monitored by controlling the demand/capacity ratio. The mass quantity was assigned to each floor at the center of mass. Rigid diaphragm was considered for the floors.

It is very important to consider the appropriate damping for nonlinear models. Inappropriate damping assumptions may lead to extravagantly unrealistic responses that considerably differ from the real responses of the buildings [42]. Perform-3D software is able to implement Rayleigh damping as well as modal damp- 
Table 1. Specifications of designed structures.

\begin{tabular}{lccc}
\hline Total number of stories & 40 & 50 & 60 \\
Core-wall height $(\mathrm{m})$ & 140 & 175 & 210 \\
Wall length $(Y$ direction), $L w(\mathrm{~m})$ & 10 & 12.5 & 15 \\
Floor plan dimension $(L 1 \times L 2)(\mathrm{m})$ & $30 \times 35$ & $37.5 \times 42.5$ & $45 \times 50$ \\
Wall thickness $(\mathrm{m})$ & 0.5 & 0.75 & 1.15 \\
Outrigger stories no. & 29,30 & 36,37 & $44,45,46$ \\
Brace cross-section area $\left(\mathrm{m}^{2}\right)$ & 0.0430 & 0.0748 & 0.1239 \\
Total seismic weight of structure (ton) & 37000 & 75000 & 138000 \\
Axial load ratio of core-wall at base (P/Agfc) & 0.155 & 0.18 & 0.197 \\
Normalized height of outrigger story (from base) & 0.73 & 0.73 & 0.74 \\
Design base shear (ton) & 2150 & 4480 & 8390 \\
Fundamental period of vibration (sec) (Y direction) & 4.42 & 5.66 & 6.64 \\
\hline
\end{tabular}

Table 2. Calculated longitudinal reinforcement for the RC core-wall.

\begin{tabular}{cccccccc}
\hline \multicolumn{2}{c}{ 40 ST } & & \multicolumn{2}{c}{$5 \mathbf{S T}$} & & \multicolumn{2}{c}{ 60 ST } \\
\cline { 1 - 2 } \cline { 7 - 8 } $\begin{array}{c}\text { No. of } \\
\text { stories }\end{array}$ & $\begin{array}{c}\text { Reinforcing } \\
\text { ratio }\end{array}$ & & $\begin{array}{c}\text { No. of } \\
\text { stories }\end{array}$ & $\begin{array}{c}\text { Reinforcing } \\
\text { ratio }\end{array}$ & & $\begin{array}{c}\text { No. of } \\
\text { stories }\end{array}$ & $\begin{array}{c}\text { Reinforcing } \\
\text { ratio }\end{array}$ \\
\hline $1-4$ & 1.27 & & $1-5$ & 1.48 & & $1-6$ & 1.72 \\
$5-8$ & 0.63 & & $6-10$ & 0.57 & & $7-12$ & 0.45 \\
$9-12$ & 0.25 & & $11-15$ & 0.25 & & $13-18$ & 0.25 \\
$13-16$ & 0.25 & & $16-20$ & 0.25 & & $19-24$ & 0.25 \\
$17-19$ & 0.25 & & $21-25$ & 0.25 & & $25-30$ & 0.25 \\
$20-21$ & 0.25 & & $26-30$ & 0.4 & & $31-37$ & 0.27 \\
$22-24$ & 0.52 & & $31-35$ & 0.77 & & $38-43$ & 0.57 \\
$25-28$ & 0.9 & & $36-37$ & 0.64 & & $44-46$ & 0.52 \\
$29-30$ & 0.78 & & $38-42$ & 0.68 & & $47-52$ & 0.57 \\
$31-34$ & 0.62 & & $43-47$ & 0.35 & & $52-60$ & 0.25 \\
$35-40$ & 0.28 & $48-50$ & 0.25 & & - & - \\
\hline
\end{tabular}

Table 3. Calculated cross-section area for columns.

\begin{tabular}{|c|c|c|c|c|c|}
\hline \multicolumn{2}{|r|}{$40 \mathrm{ST}$} & \multicolumn{2}{|r|}{$50 \mathrm{ST}$} & \multicolumn{2}{|c|}{$60 \mathrm{ST}$} \\
\hline $\begin{array}{l}\text { No. of } \\
\text { stories }\end{array}$ & $\begin{array}{c}\text { Column } \\
\text { cross-section } \\
\left(\mathbf{m}^{2}\right)\end{array}$ & $\begin{array}{l}\text { No. of } \\
\text { stories }\end{array}$ & $\begin{array}{c}\text { Column } \\
\text { cross-section } \\
\left(\mathbf{m}^{2}\right)\end{array}$ & $\begin{array}{l}\text { No. of } \\
\text { stories }\end{array}$ & $\begin{array}{c}\text { Column } \\
\text { cross-section } \\
\left(\mathbf{m}^{2}\right)\end{array}$ \\
\hline $1-10$ & 0.2624 & $1-18$ & 0.2944 & $1-20$ & 0.3424 \\
\hline $11-30$ & 0.2304 & $19-37$ & 0.2624 & $21-46$ & 0.2624 \\
\hline $31-40$ & 0.1320 & $38-50$ & 0.1551 & $47-60$ & 0.1776 \\
\hline
\end{tabular}

ing [41]. The software user guide recommends applying a combination of modal and Rayleigh dampings. In this approach, in addition to modal damping, a small value of Rayleigh damping is used to damp out highfrequency vibrations. In this study, according to the software guideline, $2.5 \%$ of the modal damping and $0.1 \%$ Rayleigh damping for the first and third modes were involved [43].

\subsection{Software verification}

The ability of fiber element models to simulate slender RC shear wall behavior was previously examined.
The results verified the accuracy of the fiber element models. The responses of the fiber model of shear wall and the experimental data for large-scale slender $\mathrm{RC}$ wall specimens under lateral cyclic loading showed good agreement [44-46]. To examine the accuracy of the RC shear wall response in the Perform-3D software, the result of an experimental program was used [23]. More data has been presented in [44].

\section{2. $R C$ core-wall modeling}

In this study, the dynamic behavior of core-wall models was estimated using a fiber element approach 

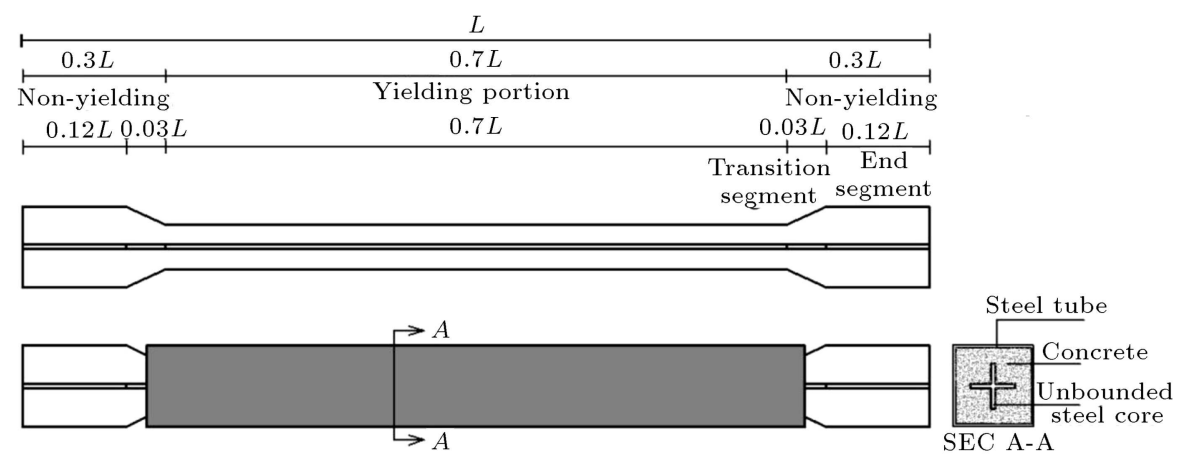

Figure 4. Parameter definition in the BRB [53].
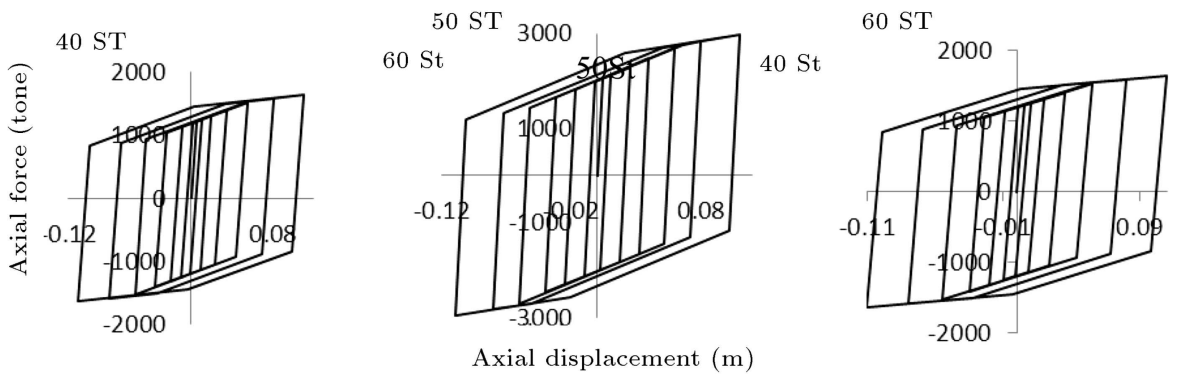

Figure 5. Hysteretic characteristics of the BRBs used in the models.

in Perform-3D software. Fiber shear wall elements were available to create cantilever RC wall model. Each element used 4 nodes and 24 degrees of freedom (Perform-3D user guide [43]). Each fiber cross-section comprised the vertical steel and concrete fibers. For nonlinear concrete fiber, a strain-stress model of confined concrete based on the modified Mander model was assumed [47]. The expected concrete compressive strength was 1.3 times the specified strength used for design. The expected yield strength of the steel bars was 1.17 times their nominal yield strength [48]. Tensile strength of the concrete was ignored. Detailed information on shear wall modeling and the expected stress-strain curves of the compressive concrete and reinforcement steel can be obtained in the work of Beiraghi et al. [49]. Figure 3 shows the elevation view of the numerical models for NLTHA. Shear behavior of the wall elements was assumed to be linear elastic. A typical value for shear stiffness is $\mathrm{GcAg} / 10$ to $\mathrm{GcAg} / 20$ as recommended by ATC72 [50]. In this study, the value of $\mathrm{GcAg} / 15$ was used for shear stiffness, where $\mathrm{GcAg}$ indicates the elastic shear stiffness.

\subsection{BRB modeling}

BRB element in the Perform-3D consists of two bars in series, including a linear portion, which represent the non-yielding zone behavior, and a nonlinear portion, which represents the behavior of restrained yielding portion [41]. The length of restrained yielding portion of a BRB element was assumed to be 0.7 times the length of node-to-node brace element. The remaining length, namely, the non-yielding zone, was assumed to be $30 \%$. Generally, the non-yielding zone consists of the transition and end segments. In order to prevent the yielding of the non-yielding zones, the cross section areas of the transition and end segments of BRBs were considered to be larger than the restrained yielding core portion. The cross-section area of transition and end segments (At and Ae) of the BRB elements were selected as 1.6 and 2.2 times the cross-section area of the restrained yielding core portion, respectively. Furthermore, the lengths of the transition and end segments were assumed to be 0.06 and 0.24 times the total length of the bracing [51]. Figure 4 plots the BRB components and Figure 5 shows the hysteretic response of the BRBs used in the structures.

\subsection{Earthquake records}

It is necessary to select a suitable set of ground motions for application in NLTHA. The response spectrum curve of the MCE level was 1.5 times the DBE response spectrum curve level [37]. A total of 14 horizontal near-fault forward directivity ground motions and 14 far-fault events were selected from the sets of ground motions of the FEMA P695 [52]. As explained before, all records were in normal direction of the fault in the earthquake events. The time histories were extracted from the PEER NGA database. The ground motion characteristics are presented in Table 4. The records were scaled based on ASCE7-2010. The ground mo- 
Table 4. FF and NF earthquake records used in the NLTHA.

\begin{tabular}{|c|c|c|c|c|c|c|c|c|}
\hline & Event name & $\begin{array}{c}\text { Peer } \\
\text { code* }^{*}\end{array}$ & Year & $\begin{array}{l}\text { Record } \\
\text { length } \\
(\mathrm{s})\end{array}$ & Station & PGA & $\mathbf{M}$ & $\begin{array}{c}\text { Site source } \\
\text { distance } \\
(\mathbf{k m})\end{array}$ \\
\hline \multirow{14}{*}{ 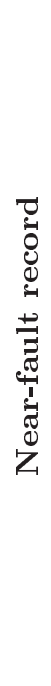 } & Imperial Valley-06 & 181 & 1979 & 39 & El Centro Array\#6 & 0.44 & 6.5 & 27.5 \\
\hline & Imperial Valley-06 & 182 & 1979 & 37 & El Centro Array\#7 & 0.46 & 6.5 & 27.6 \\
\hline & Irpinia, Italy-01 & 292 & 1980 & 40 & Sturno & 0.31 & 6.9 & 30.4 \\
\hline & Superstition Hills-02 & 723 & 1987 & 22.3 & Parachute test site & 0.42 & 6.5 & 16 \\
\hline & Loma Prieta & 802 & 1989 & 40 & Saratoga-Aloha & 0.38 & 6.9 & 27.2 \\
\hline & Erizican-Turkey & 821 & 1992 & 20.8 & Erizican & 0.49 & 6.7 & 9 \\
\hline & Cape Mendocino & 828 & 1992 & 36 & Petrolia & 0.63 & 7 & 4.5 \\
\hline & Landers & 879 & 1992 & 48 & Lucerne & 0.79 & 7.3 & 44 \\
\hline & Northridge-01 & 1063 & 1994 & 20 & Rinaldi Receiving Station & 0.87 & 6.7 & 10.9 \\
\hline & Northridge-01 & 1086 & 1994 & 40 & Sylmar-Olive View & 0.73 & 6.7 & 16.8 \\
\hline & Kocaeli/IZT & 1165 & 1999 & 30 & Izmit & 0.22 & 7.5 & 5.3 \\
\hline & Chi Chi, Taiwan & 1503 & 1999 & 90 & TCU065 & 0.82 & 7.6 & 26.7 \\
\hline & Chi Chi, Taiwan & 1529 & 1999 & 90 & TCU102 & 0.29 & 7.6 & 45.6 \\
\hline & Duzce & 1605 & 1999 & 26 & Duzce & 0.52 & 7.1 & 1.6 \\
\hline \multirow{14}{*}{ 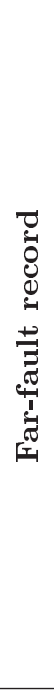 } & Northridge & 960 & 1994 & 20 & Canyon Country-WLC & 0.48 & 6.7 & 26.5 \\
\hline & Duzce & 1602 & 1999 & 56 & Bolu & 0.82 & 7.1 & 41.3 \\
\hline & Hector Mine & 1787 & 1999 & 45.3 & Hector & 0.34 & 7.1 & 26.5 \\
\hline & Imperial valley & 169 & 1979 & 100 & Delta & 0.35 & 6.5 & 33.7 \\
\hline & Imperial valley & 174 & 1979 & 39 & El Centro Array\#11 & 0.38 & 6.5 & 29.4 \\
\hline & Kobe, Japan & 1116 & 1995 & 41 & Shin-Osaka & 0.24 & 6.9 & 46 \\
\hline & Kocaeli, Turkey & 1158 & 1999 & 27.2 & Duzce & 0.36 & 7.5 & 98.2 \\
\hline & Kocaeli, Turkey & 1148 & 1999 & 30 & Arcelik & 0.22 & 7.5 & 53.7 \\
\hline & Landers & 900 & 1992 & 44 & Yermo Fire Station & 0.24 & 7.3 & 86 \\
\hline & Loma Prieta & 767 & 1989 & 40 & Gilroy Array & 0.56 & 6.9 & 31.4 \\
\hline & Superstition Hills & 721 & 1987 & 40 & El Centro lmp. Co. & 0.36 & 6.5 & 35.8 \\
\hline & Superstition Hills & 725 & 1987 & 22.3 & Poe Road (temp) & 0.45 & 6.5 & 11.2 \\
\hline & Chi Chi, Taiwan & 1244 & 1999 & 90 & Chy101 & 0.44 & 7.6 & 32 \\
\hline & San Fernando & 68 & 1971 & 28 & LA-Hollywood Stor & 0.21 & 6.6 & 39.5 \\
\hline
\end{tabular}

*: Pacific earthquake engineering research center strong motion database.

tions were scaled such that the average value of the $5 \%$ damped spectrum curve for periods in the range of $0.2 T$ to $1.5 T$ was above the target MCE level spectrum, where $T$ is fundamental period of the natural vibration of the structure. The scaled spectra for the near-fault and far-fault records are demonstrated in Figure 1.

\section{Dynamic analysis response}

The individual response envelopes and mean response envelope for the systems subjected to the NF and FF record sets are calculated. For example, the moment demand envelopes for NF records are presented in Figure 6. Figure 7 shows the mean moment demand envelope along the height of the buildings subjected to the NF and FF records. The vertical axis is normalized height and the horizontal axis is normalized moment. These values were calculated by dividing the moment demand by the seismic weight multiplied by total height of the building $(M / W . H)$. Generally, the moment demand diagram from the NF records is approximately close to the moment demand diagram from FF records. The reason is the plasticity extending all over the RC core-wall. When a cross-section exceeds plastic moment capacity, the moment demand remains approximately constant or has slight increase. Approximately, this happens all over the RC core-wall height subjected to both sets of FF and NF records; 

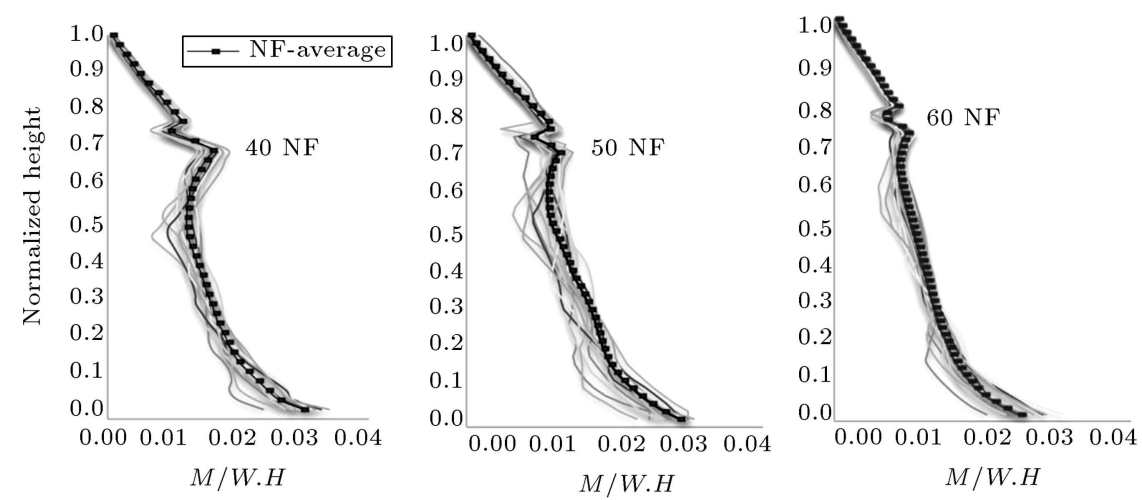

Figure 6. Individual and mean moment demand envelopes subjected to the NF records.
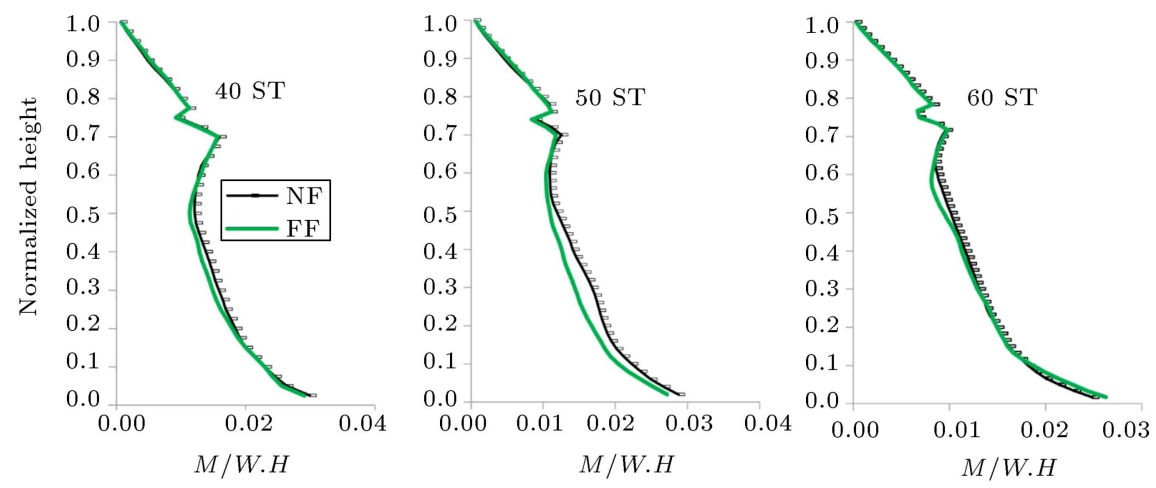

Figure 7. Comparison of the mean moment demand envelopes from NF and FF ground motions along the height of the RC core-wall.
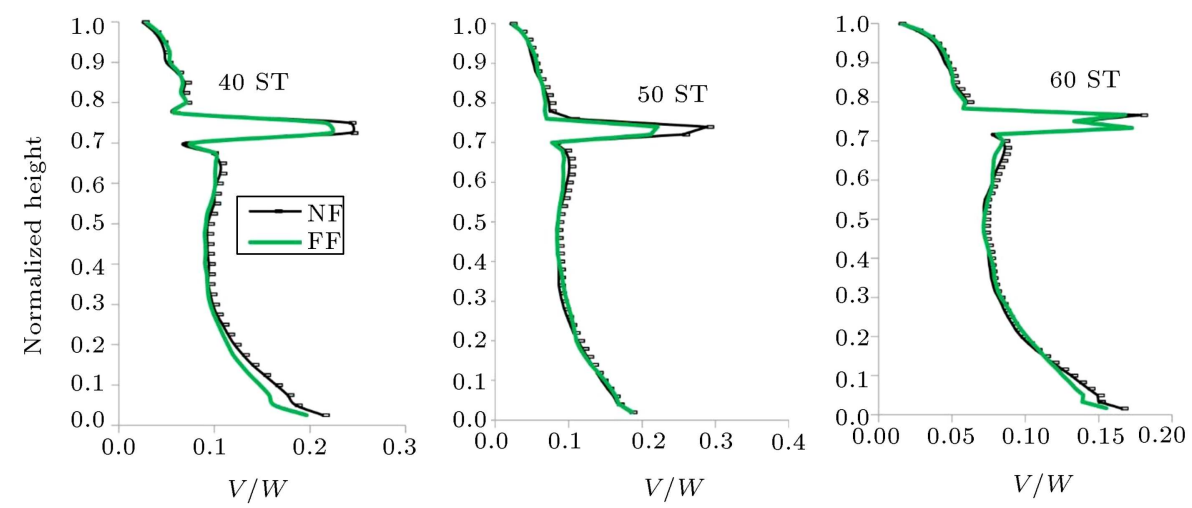

Figure 8. Comparison of the mean shear demand envelopes from NF and FF ground motions along the height of the RC core-wall.

therefore, the mean moment demand envelopes of both sets of records are similar. It is worthy to mention that some FF data in this paper has been taken from Beiraghi and Siahpolo [53].

Figure 8 shows the mean shear demand envelope along the height of the buildings subjected to the NF and FF records. The vertical axis is normalized height. The horizontal axis is normalized shear, which was calculated by dividing the shear demand by the seismic weight of the building $(V / W)$. Generally, the shear demand diagram from the NF records is approximately close to the shear demand diagram from FF records.
The reason is the plasticity extending all over the RC core-wall, which leads to almost identical shear demand, similar to that described for moment demand. When a region of the $\mathrm{RC}$ core-wall yields to flexure, approximately no more moment as well as no more lateral force can be exerted and this means no more shear force. The value of shear demand rises sharply at the outrigger levels. This is as an outcome of the action of large horizontal coupled forces resulting from outrigger performance. It causes large shear demand in the core-wall, which is larger than the base shear demand. Moreover, the shear demand in the core- 

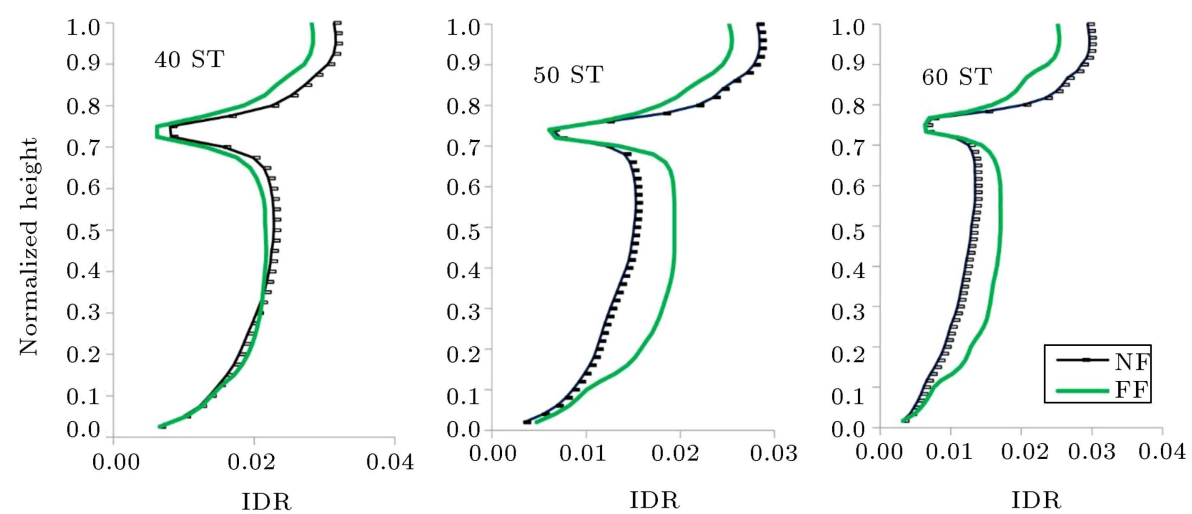

Figure 9. Comparison of the mean IDR demand envelopes from NF and FF ground motions along the height of the RC core-wall.
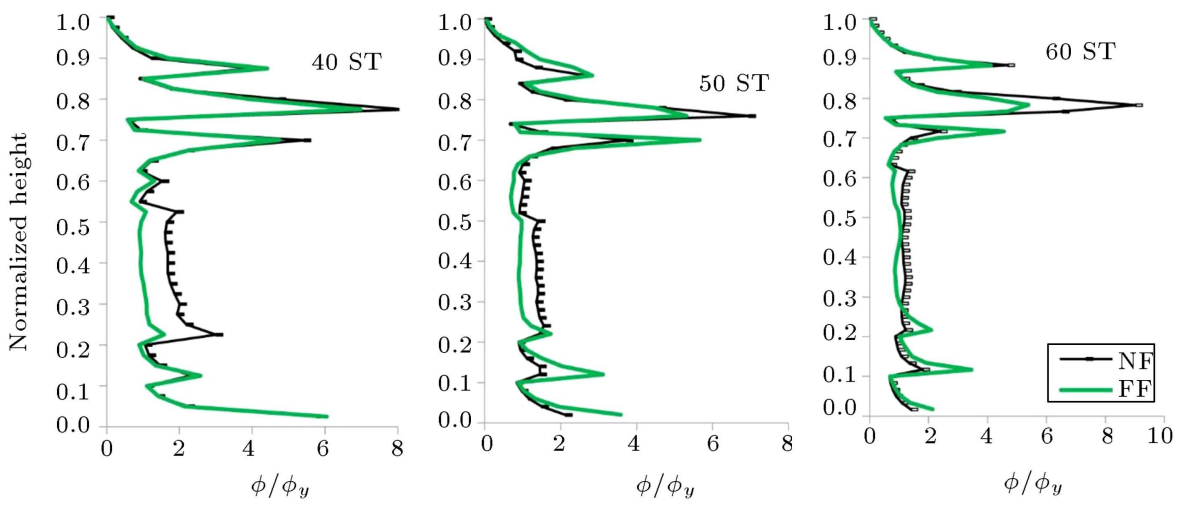

Figure 10. Comparison of the mean curvature ductility demand envelopes from NF and FF ground motions along the height of the RC core-wall.

wall at outrigger level resulting from NF is larger than the corresponding values of $\mathrm{FF}$ records due to pulse existence in the NF ground motion.

Figure 9 presents the mean Inter-story Drift Ratio (IDR) demand envelope along the height of the buildings subjected to the NF and FF records. The vertical axis is normalized height. In the 40-story building, for the areas below the outrigger level, the overall IDR demand of the $\mathrm{FF}$ records did not differ considerably from IDR demand of the NF ones. But, in areas above the outrigger level, the maximum IDR demand of the NF records was 0.0315 , which was approximately 1.1 times the IDR demand of FF records. In the 50- and 60story buildings, for the areas below the outrigger level, the IDR envelope of the FF records was larger than the IDR envelope of the NF records, while the maximum difference was approximately $35 \%$, above the outrigger levels. Generally, in all the cases, except for the 40story subjected to NF, the maximum IDR was less than $3 \%$. This value is permitted by the Los Angeles Tall Buildings Structural Design Council (LATBSDC [48]). In the 40-story buildings subjected to NF, maximum IDR exceeding $3 \%$ is insignificant.

Figure 10 shows the mean curvature ductility demand envelope along the height of the $\mathrm{RC}$ core-wall subjected to the NF and FF records. The vertical axis is normalized height. It is obvious that the plasticity extends in most areas of the RC core-wall. However, in some areas, like around $0.4 \mathrm{H}$, the curvature ductility demand value is less than 1 . In all the cases, the highest value of the curvature ductility demand was observed at levels just above the outrigger; one of the reasons is the effect of higher vibration modes and another reason is the effect of outrigger. The maximum value of curvature ductility was 9 , which belonged to $60-$ story building subjected to NF records. It occurred just above the outrigger level. The outrigger effect prevents plasticity extension in the $\mathrm{RC}$ core-wall at outrigger levels. Generally, the sudden rise in the curvature ductility demand envelope is due to change in the vertical reinforcement ratio. In the core-wall, at levels above and just beneath the outrigger, the plasticity extension is relatively considerable. Using special reinforcement details is necessary to undertake the deformation. Generally, at the base of the corewall, the taller the building, the smaller the curvature ductility demand. For the 50- and 60 -story buildings, it is obvious that the plasticity extension through the 

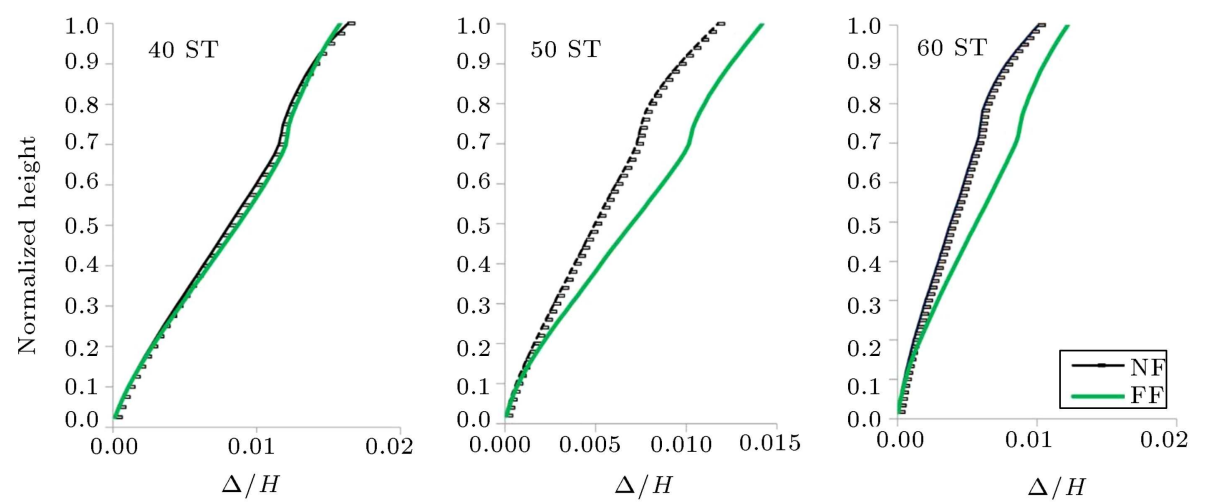

Figure 11. Comparison of the horizontal displacement demand envelopes from NF and FF ground motions along the height of the RC core-wall.
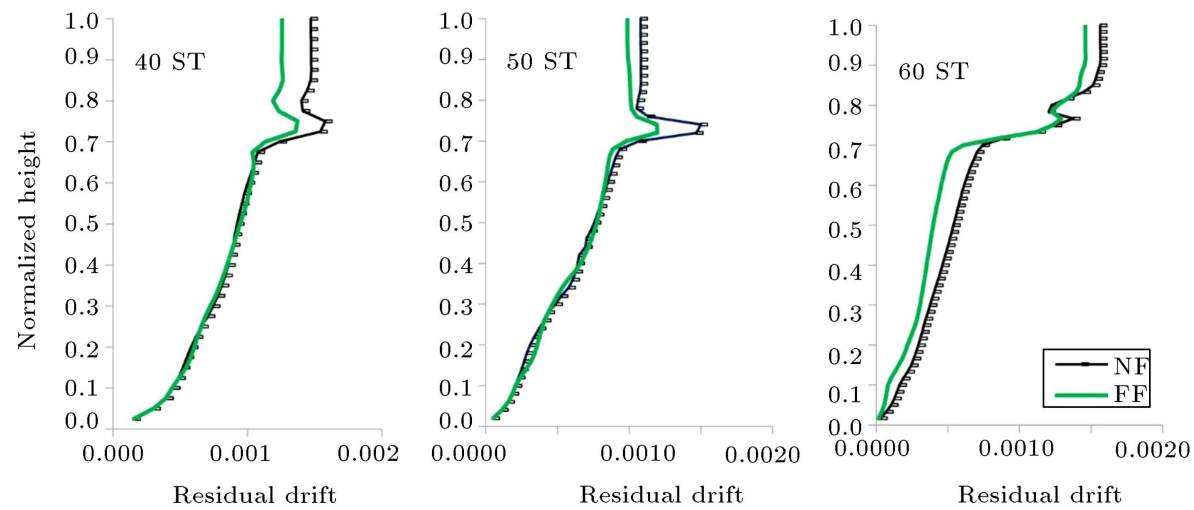

Figure 12. Comparison of the mean residual IDR demand envelopes from NF and FF ground motions along the height of the RC core-wall.

$0.1 H$ adjacent to the base is not significant. In all core-walls, at the levels above the outrigger, the overall plasticity extension using the NF records is more severe than using FF records, adversely at base level.

Figure 11 shows the mean horizontal drift demand envelope along the height of the buildings subjected to the NF and FF records. The vertical axis is normalized height and the horizontal axis is normalized displacement. These normalized values were calculated by dividing the story displacement demand by the total height of the building. For 50- and 60-story buildings, it is obvious that the roof drift ratio of $\mathrm{FF}$ records is approximately 1.2 times the roof drift ratio of $\mathrm{NF}$ records. The reason is that the curvature demand in the area near the base of the core-wall resulting from FF records is larger than corresponding values from NF records. This leads to larger rotations at lower areas and larger horizontal displacement demand at upper levels of the core-wall, which also strongly affect the roof displacement. In the 40-story building, as previously shown, the curvature ductility demands at the lower region calculated from the FF and NF records are approximately identical. Therefore, the displacement demands resulting from the FF and NF records are also approximately identical. In all the cases, the slope of the mean displacement demand envelope increases just above the outrigger level due to the outrigger action on the building local drift.

The mean residual IDR envelope along the height of the buildings subjected to the NF and FF records is shown in Figure 12. The vertical axis is normalized height. According to the LATBSDC, the mean absolute values of residual IDR from a suite of analyses should not exceed 0.01 for MCE earthquake level. For all the examined cases, the maximum residual IDR was less than 0.002 , which is considerably lower than the allowable values. The difference between residual IDRs obtained from NF and FF records was not significant. The increase in residual IDR envelope at outrigger level was because of axial inelastic deformation of steel core in the BRBs. It leads to permanent axial deformation in them and, therefore, comparatively larger residual deformation in the outrigger stories.

In some researches, numerical studies on the behaviors of tall RC core-wall buildings have indicated that high-rise RC core-walls subjected to $\mathrm{NF}$ ground motion excitations at Maximum Considered Earthquake (MCE) level experience considerable floor accelerations that may exceed the peak ground acceleration [54]. Figure 13 plots the mean floor acceleration 

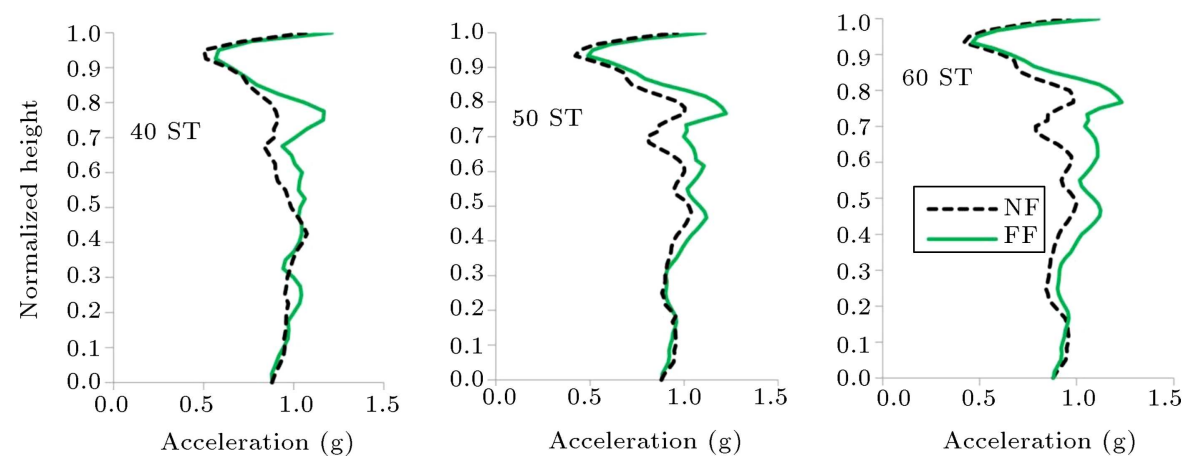

Figure 13. Comparison of the horizontal floor acceleration demand envelopes from NF and FF ground motions along the height of the RC core-wall.
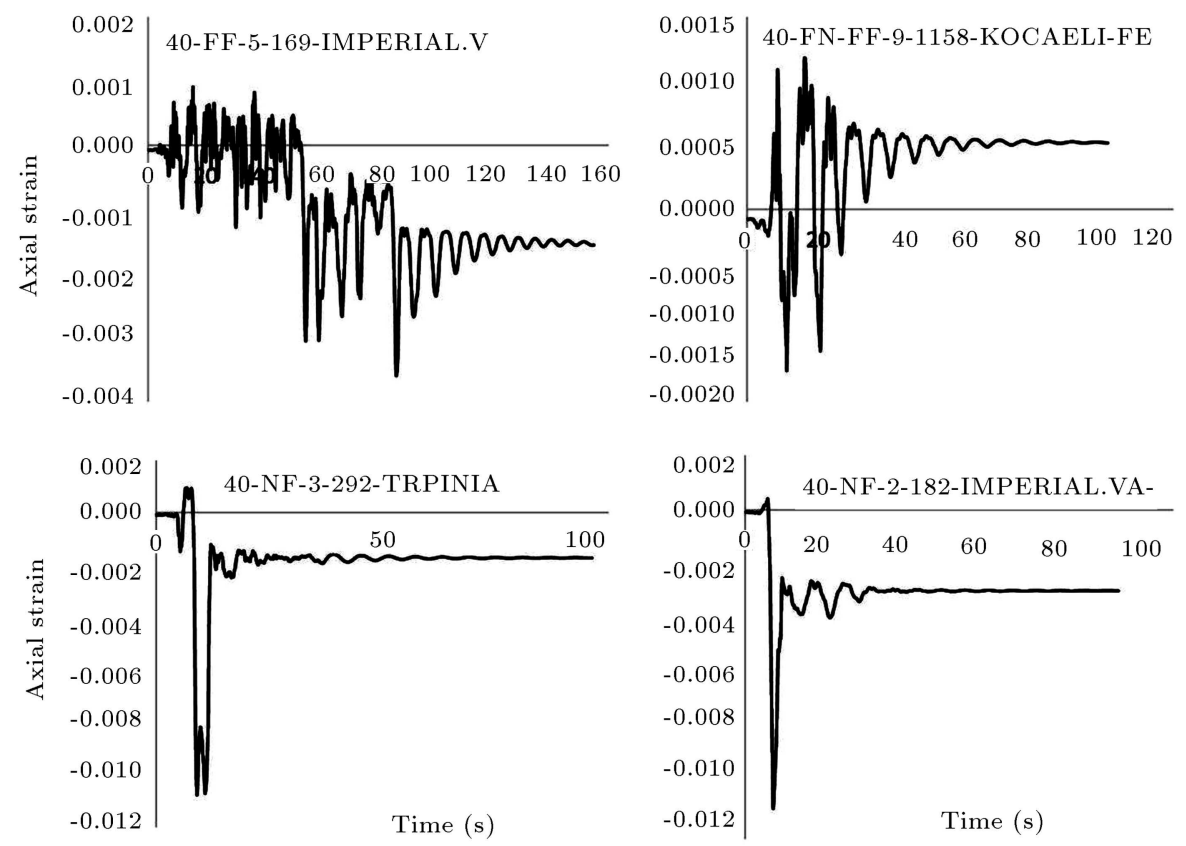

Figure 14. Time history of axial strain in the core of BRB for two typical NF and FF records in the 40-story structure.

demand of the systems subjected to the NF and FF records. The maximum floor acceleration belongs to the FF records and occurs near the outrigger level. On average, for $\mathrm{FF}$ events, the maximum floor acceleration is larger than 1.3 times the peak ground acceleration. For NF records, this ratio is approximately 1.07 .

In the 40-story structure, time history of the axial strain in the BRB core for two typical NF and FF records is detected in Figure 14. Commonly, for the $\mathrm{NF}$ records, the axial strain in the BRB core has one significant sudden increase due to pulse existence in the NF records. But, for ordinary FF records, more oscillations without distinctly sudden increases appear in the axial strain time history of the BRB core. The mean maximum strain from FF and NF records, obtained from the time history analysis, is demonstrated in Figure 15. The mean maximum strains in the BRB cores obtained from both record sets were less than 10 times the expected yielding strain (0.0014). These values were within the acceptable limits [40]. Generally, it seems that a response modification factor of 5 is an almost reasonable value for the $\mathrm{RC}$ corewall with BRB outriggers for FF earthquakes and NF earthquakes. The overall mean responses of the structures are within acceptable range. Furthermore, it is worthy to note that the outcomes of this paper cannot be generalized for all similar structures and further research is required to reach more extensive conclusions.

\section{Conclusions}

In this paper, behavior of reinforced concrete corewall structures connected to the outside columns by BRB outriggers in tall buildings subjected to forward directivity NF and ordinary FF ground motions was 


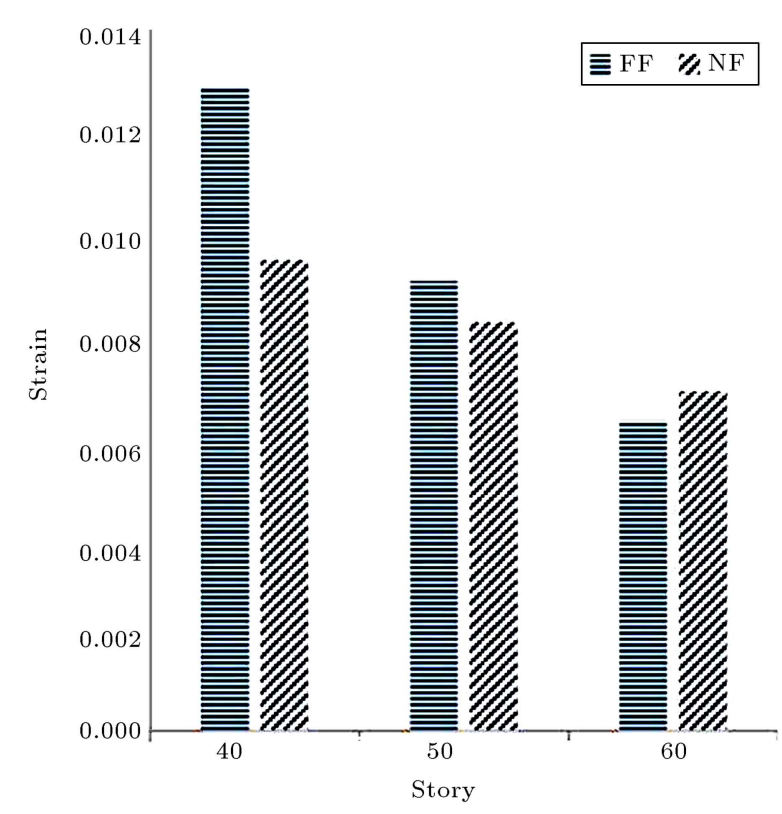

Figure 15. Mean maximum strains in the core of the BRBs for FF and NF records.

investigated. The outrigger was assumed to be approximately at $0.74 \mathrm{H}$. According to the current codes for DBE level, RSA procedure was used to analyze and design the structures. Nonlinear fiber element approach was used to model reinforced concrete corewalls. For nonlinear dynamic analysis, $14 \mathrm{NF}$ as well as 14 FF records were implemented at MCE level. The investigations resulted in the following conclusions:

1. The maximum mean IDR envelope is roughly less than 3\% that is permitted by the Los Angeles Tall Buildings Structural Design Council. The maximum mean IDR envelope of NF records is generally larger than the corresponding value of $\mathrm{FF}$ records by a factor of 1.1 ;

2 . The highest value of mean curvature ductility demand envelope in the core-wall was observed at levels just above the outrigger; one reason is the effect of higher vibration modes. Besides, at these levels, the overall plasticity extension using the NF records is more severe than that using FF records, adversely, at base level. Generally, at the base of the core-wall, the taller the building, the smaller the curvature ductility demand;

3. For taller buildings, the mean roof drift ratio demand envelope calculated from FF records is larger than that from NF records. This is related to the curvature ductility demand envelope, especially at the base, as mentioned in the previous case;

4. In all the examined cases, the maximum residual IDR was less than 0.002 , which is considerably lower than the allowable values;

5. The overall responses of the $\mathrm{RC}$ core-wall with
BRB outrigger system are in acceptable range for FF earthquakes and approximately for NF earthquakes. It seems that a response modification factor of 5 is an almost reasonable value for these systems;

6. The maximum floor acceleration belongs to the FF records and occurs near the outrigger level. On average, for FF events, the maximum floor acceleration is larger than 1.3 times the peak ground acceleration. For NF records, this ratio is approximately 1.07 .

\section{References}

1. Rahgozar, R. and Sharifi, Y. "An approximate analysis of framed tube shear core and belt truss in highrise building", Structural Design of Tall and Special Buildings, 18, pp. 607-624 (2009).

2. Smith, B.S. and Coull, A., Tall Building Structures: Analysis and Design, 1 Ed., New York: John Wiley \& Sons Inc (2011).

3. Smith, B.S. and Salim, I. "Parameter study of outrigger-braced tall building structuresm", Journal of the Structural Division, 107(10), pp. 2001-2014 (1981).

4. Taranath, B.S., Structural Analysis and Design of Tall Buildings, New York, McGraw Hill (1988).

5. Malekinejad, M. and Rahgozar, R. "Free vibration analysis of tall buildings with outrigger-belt truss system", Earthquake and Structures, 2(1), pp. 89-107 (2011).

6. Zhu, Y. "Inner force analysis of frame-core structure with horizontal outrigger belts", Journal of Building Structures, 10, pp. 10-15 (1995).

7. Taranath, B.S. "Optimum belt truss location for high rise structures", Engineering Journal, 11(1), pp. 18-21 (1974).

8. Rutenberg, A. and Tal, D. "Lateral load response of belted tall building structures", Engineering Structures, 9(1), pp. 53-67 (1987).

9. Wu, J.R. and Li, Q.S. "Structural performance of multi-outrigger-braced tall buildings", The Structural Design of Tall and Special Buildings, 12(2), pp. 155176 (2003).

10. Zhou, Y. and Li, H. "Analysis of a high-rise steel structure with viscous damped outriggers", The Structural Design of Tall and Special Buildings, 23(13), pp. 963979 (2013).

11. Chang, C.M., Wang, Z., Spencer, B.F., and Chen, Z. "Semi-active damped outriggers for seismic protection of high-rise buildings", Smart Structures and Systems, 11(5), pp. 435-451 (2013).

12. Bobby, S., Spence, M.J.S., Bernardini, E., and Kareem, A. "Performance-based topology optimization for wind-excited tall buildings: a framework", Engineering Structures, 74, pp. 242-255 (2014). 
13. Lee, S. and Tovar, A. "Outrigger placement in tall buildings using topology optimization", Engineering Structures, 74, pp. 122-129 (2014).

14. Chen, Y., McFarland, D., Wang, Z., Spencer, B., Jr., and Bergman, L.A. "Analysis of tall buildings with damped outriggers", Journal of Structure Engineering, 136(11), pp. 1435-1443 (2010).

15. Bosco, M. and Marino, E.M. "Design method and behavior factor for steel frames with buckling restrained braces", Earthquake Engineering \& Structural Dynamics, 42, pp. 1243-1263 (2013).

16. AISC, Seismic Provision for Structural Steel Buildings, American Institute of Steel Construction: Chicago (2010).

17. Asgarian, B. and Shokrgozar, H.R. "BRBF response modification factor", Journal of Constructional Steel Research, 65, pp. 290-298 (2009).

18. Kim, J., Park, J., and Kim, S. "Seismic behavior factors of buckling restrained braced frames", Structural Engineering and Mechanics, 33(3), pp. 261-284 (2009).

19. Klemencic, R., Fry, A., Hooper, J.D., and Morgen, B.G. "Performance based design of ductile concrete core wall buildings-issues to consider before detail analysis", The Structural Design of Tall and Special Buildings, 16, pp. 599-614 (2007).

20. CSA Standard A23.3-04, Design of Concrete Structures, Canadian Standard Association: Rexdale, Canada; 214 (2005).

21. NZS 3101 "New Zealand standard, Part 1- The design of concrete structures", Standards New Zealand: Wellington, New Zealand (2006).

22. CEN EC8 "Design of structures for earthquake resistance", European Committee for Standardization: Brussels, Belgium (2004).

23. Ghorbanirenani, I., Tremblay, R., Léger, P., and Leclerc, M. "Shake table testing of slender RC shear walls subjected to eastern North America seismic ground motions", Journal of Structural Engineering, 138(12), pp. 1515-1529 (2012).

24. Beiraghi, H., Kheyroddin, A., and Kafi, M.A. "Effect of record scaling on the behavior of reinforced concrete core-wall buildings subjected to near-fault and farfault earthquakes", Scientia Iranica A, 24(3), pp. 884899 (2016).

25. Gerami, M. and Siahpolo, N. "Proposition of a new method for quick assessment of maximum beam ductility in steel moment frame under higher mode effects", Scientia Iranica A., 23(3), pp. 769-787 (2016).

26. Bertero, V., Mahin, S., and Herrera, R. "A seismic design implications of near-fault San Fernando earthquake records", Earthquake Engineering and Structural Dynamics, 6(1), pp. 31-42 (1978)

27. Anderson, J.C. and Bertero, V.V. "Uncertainties in establishing design earthquakes", Journal of Structural Engineering, 113(8), pp. 1709-1724 (1987).
28. Baker, J.W. "Quantitative classification of near-fault ground motions using wavelet analysis", Bulletin of the Seismological Society of America, 97(5), pp. 1486-1501 (2007).

29. Gerami, M. and Abdollahzadeh D. "Numerical study on energy dissipation of steel moment resisting frames under effect of earthquake vibrations", Advances in Acoustics and Vibration, Article ID 510593, pp. 1-13 (2014).

30. Gerami, M. and Abdollahzadeh, D. "Estimation of forward directivity effect on design spectra in near field of fault", J. Basic. Appl. Sci. Res., 2(9), pp. 8670-8686 (2012).

31. Mortezaei, A. and Ronagh, H.R. "Plastic hinge length of reinforced concrete columns subjected to both farfault and near-fault ground motions having forward directivity", Structural Design of Tall and Special Buildings, 22(12), pp. 903-926 (2013).

32. Somerville, P.G., Smith, N.F., Graves, R.W., and Abrahamson, N.A. "Modification of empirical strong ground motion attenuation relations to include the amplitude and duration effects of rupture directivity", Seismological Research Letters, 68(1), pp. 199-222 (1997).

33. Beiraghi, H., Kheyroddin, A., and Kafi, M.A. "Forward directivity near-fault and far-fault ground motion effects on the behavior of reinforced concrete wall tall buildings with one and more plastic hinges", The Structural Design of Tall and Special Buildings, 25(11), pp. 519-539 (2016).

34. Taranath, B.S., Structural Analysis and Design of Tall Buildings, New York, McGraw Hill (1988).

35. ETABS, Version 13.1.1. "Computers and structures", Inc.: Berkeley, California, USA (2013).

36. National Institute of Standards and Technology "Seismic design of cast-in-place concrete special structural walls and coupling beams", NEHRP Seismic Design Technical Brief No. 6 (2012).

37. ASCE/SEI 7 "Minimum design loads for buildings and other structures", American Society of Civil Engineers, Reston, VA (2010).

38. ACI 318-11 "Building code requirements for structural concrete and commentary", ACI Committee 318, Farmington Hills (2011).

39. Sahoo, D.R. and Chao, S. "Performance-based plastic design method for buckling-restrained braced frames", Engineering Structures, 32, pp. 2950-2958 (2010).

40. Jones, P. and Zareian, F. "Seismic response of a 40storey buckling-restrained braced frame designed for the Los Angeles region", The Structural Design of Tall and Special Buildings, 22(3), pp. 291-299 (2013).

41. PERFORM-3D "Nonlinear analysis and performance assessment for 3D structures", V.4.0.3., Computers and Structures, Inc., Berkeley, CA (2011).

42. Léger, P. and Dussault, S. "Seismic-energy dissipation in MDOF structures", Journal of Structural Engineering, 118(5), pp. 1251-1269 (1992). 
43. PERFORM-3D "Nonlinear analysis and performance assessment for 3D structures", V.4, User Guide, Computers and Structures, Inc., Berkeley, CA (2006).

44. Beiraghi, H., Kheyroddin, A., and Kafi, M.A. "Nonlinear fiber element analysis of a reinforced concrete shear wall subjected to earthquake records", Transactions of Civil Engineering, 39(C2+), pp. 409-422 (2015)

45. Orakcal, K. and Wallace, J.W. "Flexural modeling of reinforced concrete walls-experimental verification", ACI Structural Journal, 103(2), pp. 196-206 (2006).

46. Luu, H., Ghorbanirenani, I., Léger, P. and Tremblay, R. "Numerical modeling of slender reinforced concrete shear wall shaking table tests under high-frequency ground motions", Journal of Earthquake Engineering, 17(4), pp. 517-542 (2013).

47. Mander, J.B., Priestley, M.J.N., and Park, R. "Theoretical stress-strain model for confined concrete", ASCE Journal of Structural Engineering, 114(8), pp. 1804-1826 (1988)

48. LATBSDC "An alternative procedure for seismic analysis and design of tall buildings located in the Los Angeles region", Los Angeles Tall Buildings Structural Design Council (2014).

49. Beiraghi, H., Kheyroddin, A., and Kafi, M.A. "Energy dissipation of tall core-wall structures with multiplastic hinges subjected to forward directivity nearfault and far-fault earthquakes", The Structural Design of Tall and Special Buildings, 25(15), pp. 801-820 (2016).

50. Applied Technology Council "ATC-72: Modeling and acceptance criteria for seismic design and analysis of tall building", ATC, Redwood City, CA (2010).

51. Nguyen, A.H., Chintanapakdee, C., and Hayashikawa, $\mathrm{T}$. "Assessment of current nonlinear static procedures for seismic evaluation of BRBF buildings", Journal of Constructional Steel Research, 66(8-9), pp. 1118-1127 (2011).

52. FEMA P695 "Quantification of building seismic performance factors (ATC-63 Project)", Federal Emergency Management Agency, Washington D.C. (2009)

53. Beiraghi, H. and Siahpolo, N. "Seismic assessment of $\mathrm{RC}$ core-wall building capable of three plastic hinges with outrigger", The Structural Design of Tall and Special Buildings, 26(2), p. e1306 (2016).

54. Calugaru, V. and Panagiotou, M. "Response of tall cantilever wall buildings to strong pulse type seismic excitation", Earthquake Engineering and Structural Dynamics, 41, pp. 1301-1318 (2012).

\section{Biography}

Hamid Beiraghi was born in 1979 in Sangesar. He obtained his BS degree in Civil Engineering from the Department of Civil Engineering at Sharif University of Technology, Iran, in 2000; his first MS degree in Construction Management and Engineering from Tehran University, Iran, in 2002; his second MS degree in Earthquake Engineering from International Institute of Earthquake Engineering and Seismology, Iran, in 2006; and his $\mathrm{PhD}$ degree in Structural Engineering from Semnan University, Iran, in 2015. His research focuses on the tall building response under near-fault pulselike earthquakes and design of core-wall structures. He has published more than 30 journal and conference papers, and one book. He is a faculty member of Azad University, Sangesar, Iran. 